\title{
Chrzest Polski w polskim dyskursie rocznicowym
}

\section{The Baptism of Poland in Polish discourse devoted to the anniversary}

\author{
Joanna Sobczykowa \\ Wydział Filologiczny, Uniwersytet Śląski w Katowicach, \\ pl. Sejmu Śląskiego 1, 40-032 Katowice, Polska; \\ e-mail: jsobczykowa@wp.pl
}

\begin{abstract}
Abstrakt
Autorka analizuje dyskurs poświęcony rocznicy Chrztu Polski jako część współczesnego polskiego dyskursu tożsamościowego. Obserwuje synonimiczne nazwy faktu historycznego, jego wartościowanie, komponenty; pogłębianie sensu: następstwa, relację religijność - państwowość (narodowość); wyrażanie pamięci (początek, tożsamość); język i metajęzyk wypowiedzi.

Pokazuje różne wartościowanie historyczności, sakralności i europejskości, różne postawy uczestników wobec przekazywanej idei, niejednolite cele komunikacyjne, uwikłania światopoglądowe, osłabione poczucie wspólnoty kulturowej i narodowej, a zarazem swobodę i wyrafinowane posługiwanie się językiem.
\end{abstract}

Słowa kluczowe: dyskurs; chrzest; wartość; naród; symbolika kolektywna.

\begin{abstract}
The author analyzes discourse devoted to the anniversary of the Baptism of Poland as part of contemporary Polish identity discourse. She notices synonymic names of the historic event, its evaluation, components, elaborations on its meaning, consequences, the relationship between religion and state (nationality), expressing remembrance (beginning, identity), the language and metalanguage of statements. She shows different evaluations of historicity, the sacred, and Europeanism, various attitudes of participants towards the ideas communicated, varied communicative goals, mixing of worldviews, a weakened sense of cultural and national community, and also freedom and sophistication in the use of language.
\end{abstract}

Keywords: discourse; baptism; value; nation; collective symbols.

Punkt wyjścia moich rozważań stanowi pojęcie silnie utrwalone w świadomości i języku Polaków, należące do obowiązkowej minimalnej wiedzy historycznej każdego obywatela, nabywanej w szkole. Zawiera się ono w formule wiążącej najwcześniejszą datę roczną z historii Polski z nazwą sakramentu inicjacji chrześcijańskiej: „966 - chrzest Polski”. Obserwowałam jego użycie w wypowiedziach 
prasowych - głównie religijnych ${ }^{1}$, z lat 2015-2016, poruszających problematykę obchodzonej rocznicy, a więc tworzących dyskurs, rozumiany jako 'zdarzenie komunikacyjne związane z przekazem idei, obejmujące uczestników, ich postawy, cele komunikacyjne, uwikłania światopoglądowe, poczucie wspólnoty kulturowej' (Wojtak 2011: 28-29). Stwierdzono, że „mimo sygnalizowanego przez badaczy współczesności zróżnicowania wzorów kulturowych i systemów wartości przeciętny mieszkaniec dzisiejszej Polski [...] nie przestał określać się przede wszystkim w kategoriach narodowych" (Bartmiński 2012: 209-210), co potwierdzają socjologowie. Jako cechy o historycznych korzeniach wskazuje się: patriotyzm i odwagę, znajomość historii, katolicyzm [...], w obrębie stereotypu narodowego Polaków, będącego nie tylko utrwalonym społecznie owocem tradycji, ale także rezultatem aktualnych wydarzeń politycznych i społecznych (Szadura 1993: 247). Wysoką rangę chrześcijaństwa ukazują popularne ,skrzydlate słowa": Polska przedmurzem chrześcijaństwa; Polak, jedyny obrońca Maryi, a wspólnota narodowa i religijna Polaków dawała się odczuć wyraźnie w czasie pielgrzymek papieskich.

Poddałam oglądowi centralny współczesny termin oficjalny rocznica Chrztu Polski, złożony z komponentu sakralnego i etnicznego, w ramie solemnizacyjnej, realizowanej leksemami języka ogólnego (kulturalnego): rocznica, święto, obcho$d y$, jubileusz. Obserwowałam też terminy synonimiczne wobec oficjalnego, najczęstszego - niemetaforyczne i metaforyczne; synonimiczne nazwy faktu historycznego; jego wartościowanie; spojrzenie na jego komponenty (podmiot czynu i jego motywację, udział podmiotu pomocniczego, miejsce, czas, szafarza sakramentu; imię chrzestne, źródła pisane); pogłębianie sensu: następstwa, relację religijność - państwowość (narodowość); wyrażanie pamięci (początek, tożsamość); język i metajęzyk wypowiedzi.

Frazem najbardziej rozpowszechniony - rocznica Chrztu Polski wykazuje w obserwowanym materiale warianty oficjalne, standardowe, niekreowane. Nie są one nastawione na zaskoczenie czytelnika słownictwem lub składnią. Niektóre odchodzą od utrwalonej konstrukcji (te lokalizuję): „1050-lecie Chrztu Polski”, „rocznica Chrztu Narodu”, „po 1050 latach od Chrztu Polski”, „1050 lat chrześcijańskiej Polski / chrześcijańskiego dziedzictwa”. Wzmocnione sygnały religijności (dziękczynienie, tajemnica) zawiera wyrażenie: ,narodowe dziękczynienie za tajemnicę Chrztu naszego Narodu przed 1050 laty”. Bywają i konstrukcje narracyjne: „Przed świętami Wielkiej Nocy roku Pańskiego 966 Mieszko stanął nad brzegami basenu chrzcielnego” (Panfil 2016: V); „Od 40 pokoleń Polacy przekazują i wyznają wiarę, którą przyjął Mieszko" ([notka redakcyjna] G 16/2016: 3). Polska jest adresatem pozdrowienia i beneficjentem dokonanego chrztu w wypowiedzi pol-

${ }^{1}$ Cytaty pochodzą z następujących źródeł prasowych: „Angora” (A), „Don Bosco” (DB), „Gość Niedzielny” (G), „Gazeta Polska” (GP), „Niedziela” (N), „Polityka” (P), „Źródło” (Ź); przy lokalizacji cytatów niemających autora pierwsza liczba oznacza numer czasopisma, druga - rok, ostatnia - stronę. Cyfrą rzymską oznaczam stronicę dodatku. Jako pierwsze cytuję wypowiedzi o postawie czci. Przywołania streszczające poprzedzam skrótem por. 
skiego Papieża w Gnieźnie 1979 r.: „Pozdrawiam Polskę ochrzczoną tutaj przed tysiącem z górą lat!", przywołanej w tekście Lidii Dudkiewicz (2016d: 15).

Synonimy metaforyzujące to $\mathrm{np}$. wyrażenie potoczne z asocjacją familiarności: „Urodziny Kościoła i państwa”; 1050 „«urodziny» naszego Narodu i Ojczyzny" (Dudkiewicz L. 2016c: 3). Potocznie brzmi fraza wpisana w zarys obszaru Polski „Jezus w Polsce mieszka od 966”, spotykana wielokrotnie na łamach „Gościa Niedzielnego" w roku 2016. Metaforę religijną zawiera fraza „Naród otrzymał [...] w 966 r. klucz do Nieba ${ }^{2}$ i narodziło się państwo polskie" (Dudkiewicz W. 2016: 3). W terminologii religijnej mieści się wyrażenie „Obmyci przed 1050 laty łaską chrztu św." (Tomoń 2016: 8). Formuła sakramentalna chrztu ze zwrotem do osoby przyjmującej chrzest wypełniona jest imieniem kraju, na tle rysunku wody: „Polsko, ja ciebie chrzczę... 966-2016” ([brak autora] G 16/2016: 1). Bywają też formuły pierwszoosobowe, jak autoprezentacja Polaków w relacji genetycznej wobec chrztu, chociaż bez terminologii religijnej (nazwę sakramentu zastępuje metonimicznie nazwa żywiołu będącego jego materią): „My, ludzie z wody” (Gancarczyk 2016: 3); w terminologii biologicznej (oddech) na tle rysunku ryby i dat 966-2016: „Od czasów Mieszka I oddychamy chrześcijaństwem”(N 17/2016: 14, 2 i okładka); w terminologii genetyki: „Chrzest Polski - nasze DNA” (G 16/2016: 3). Ku domenie politycznej kieruje się porównanie „Chrzest jak Unia" (Szostkiewicz 2016: 14).

W wielu wypowiedziach analizowane wyrażenie pojawia się z czyimś, na ogół wysokim, wartościowaniem rocznicy bądź jej obchodów. Yu-Ying z Tajwanu, egzotyczny gość, ,jest zachwycona jubileuszem 1050-lecia Chrztu Polski” (Kluba 2015: 40). Kardynał Pietro Parolin eksponuje wielkość i wiarę polskiego narodu: „Ojciec Św. udzielił błogosławieństwa wielkiemu chrześcijańskiemu narodowi" (Żaryn 2016: 35). Komentarz do obrazu Jana Matejki Zaprowadzenie chrześcijaństwa zawiera wysoką ocenę tego faktu przez patriotów XIX w., widzących w nim triumf nad pogaństwem i słuszną decyzję Mieszka wprowadzenia Polski do chrześcijańskiej Europy (por. Szostkiewicz 2016: 14). Eksplicytna ocena własna długotrwałości wiary jako najwyższej wartości narodu implikuje chrzest jako fakt inicjujący: „Nie mamy jako naród nic cenniejszego niż nasza wiara, niż wierność Bogu i Kościołowi od 1050 lat” (Jaklewicz 2016: 21); akcentuje się „czas szczególnej łaski” związany z rocznicą (Dudkiewicz L. 2016d: 14). W cytacie biblijnym wyraża się wielką wartość samego chrztu: „Naród tonący w ciemnościach ujrzał światłość" (Łuczak 2016: 10-11). Sakralizację superlatywną znajdujemy w formule modlitwy - prośby o błogosławieństwo: „W najświętszą Rocznicę Chrztu Polski Ojczyznę wolną pobłogosław, Panie"4.

${ }^{2}$ Klucze do królestwa niebieskiego przekazał Jezus Piotrowi (Mt 15,16), co jest znakiem prymatu Piotra. Por. Klucz [hasło] (Langkammer 1994: 87). Cytowana fraza ma jednak sens szerszy.

3 Nagłówek zapowiadający główny temat „Gościa Niedzielnego”.

${ }^{4}$ N 16/2016: 42. (brak autora, tytuł Wieczór 206). 
Dumę narodu ze swej ponadtysiącletniej tradycji eksponuje się w cytacie z preambuły Konstytucji z 22 kwietnia 1997: „My, Naród Polski [...] wdzięczni naszym przodkom za ich pracę, za walkę o niepodległość okupioną ogromnymi ofiarami, za kulturę zakorzenioną w chrześcijańskim dziedzictwie Narodu i ogólnoludzkich wartościach" (Nowak 2015: 74).

Zaskakującą analogię wydobywa przytaczany z Facebooka ironizujący mem z sądem opartym na relatywizacji wartości rocznicowych, odwracający wartościowanie, na modłę spotykanego dziś argumentu przeciw nowościom ideologicznym: „1050 lat temu Mieszko I porzucił tradycyjne wartości swojego narodu i przyjął modną ideologię narzuconą przez Europę Zachodnią" (Szczerek 2016: $16)$.

Sceptycy podważają też zasadność rocznicy „bardzo okrągłej, bo 1050.”, z czytelną aluzją do miesięcznic tragedii smoleńskiej: „w dobie miesięcznic takie rzeczy przestają razić" (Szczerek 2016: 16). Ukuto nawet termin rocznicowy eksponujący naddatek rachunkowy - bez eksponentu celebracji, z lekką ironią „Milenium $+50 "$ ".

\section{Komponenty faktu historycznego}

Motywacja czynu przez jego podmiot. Stając przed dylematem: „Chrzest z wiary czy z polityki?" (Gancarczyk 2015: 3), twierdzi się, że zupełne pomijanie motywacji religijnej pierwszego władcy, jak w powszechnym przekazie czasu minionego, jest nieporozumieniem (Gancarczyk 2016: 3); wyraźnie taką tezę zawiera tytuł książki historyka Philipa Steele'a (2016) Nawrócenie i chrzest Mieszka I (Kabiesz 2016: 3). Podkreśla się wszakże i motyw polityczny książęcej decyzji: „Polska weszła przez Chrzest w 966 r. w obszar kulturowy cywilizacji łacińskiej i chrześcijańskiej - była to najważniejsza w naszej historii decyzja polityczna podjęta przez polskiego władcę" (Łysiak 2016: III). Dostrzega się chęć umocnienia dzieła ojca i wprowadzenia kraju do chrześcijańskiego świata jako „ówczesną rację stanu”, chociaż zamiar pomocy Ottonowi III w budowie potężnej wspólnoty ludów chrześcijańskich pozostaje pytaniem (Wroński 2016: VII).

Sceptycy z lekceważeniem piszą o przedsięwzięciu i motywacji Piastów, prowincjonalnych władyków z niewielkiego gródka, handlujących własnymi poddanymi, sprzedawanymi jako niewolnicy; , ,[...] stopniowo nabierali ochoty na coraz większe międzynarodowe znaczenie, przyjęli więc chrzest, by w Europie brano ich poważnie. Minęło tysiąc lat, wydarzyła się cała ta przygoda, nad którą dziś dzieci ziewają na historii” (Szczerek 2016: 16-17).

Ważnym komponentem rekonstrukcji i oceny wydarzenia sprzed 1050 lat pozostaje rola Dobrawy w chrystianizacji Polski. Według kronikarza Thietmara istotnie przyczyniła się ona do nawrócenia Mieszka, co należy uważać za fakt, nie zaś jedynie rys średniowiecznej konwencji literackiej (Panfil 2016: V; Grajewski 2015: 37). Jej pozycja jako przedstawicielki narodu o głębszej duchowości i wyż- 
szej kulturze była mocna, ale i książęcy zamysł wprowadzenia Polski do zachodniej cywilizacji był bardzo ważny (Różycki 2016: 15). Sceptykom trudno uwierzyć, żeby przez rok namawiała Mieszka na chrzest. Jego decyzję widzą jako czysto polityczną (Szostkiewicz 2016: 15). Domniemana scena domowej rozmowy księcia z żoną i biskupem tuż przed chrztem pokazuje, że decydująca była dla niego legitymizacja władzy: „mieć taką podkładkę do rządzenia” (Wakuła 2016: 2).

Jako miejsce chrztu przyjmuje się Poznań, Ostrów Lednicki bądź Gniezno (Śliwa 2016: 20); według nowych danych to raczej Poznań był stolicą państwa; innymi głównymi siedzibami księstwa były Giecz i Ostrów Lednicki; dopuszcza się hipotezę chrztu w Ratyzbonie (Panfil 2016: V). Spotyka się też zdania, że Ratyzbona czy Praga są mało prawdopodobne (Różycki 2016: 14). Czas tego wydarzenia wyznacza się między rokiem 964 a 966 (Panfil 2016: V): rok - na podstawie rocznika krakowskiego, datę dzienną - z tablic paschalnych (Różycki 2016: 14). Kto chrzcił Mieszka I? Akt takiej wagi, jak przyjęcie świętej wiary katolickiej przez potężnego księcia Północy i jego dwór, wymagał odpowiedniej ceremonialnej oprawy. Niewątpliwie chrzcić musiał biskup (Panfil 2016: V); był to prawdopodobnie biskup Jordan (kapelan Dobrawy?); (Grajewski 2016: 24). Pojawiają się informacje o domysłach co do imienia chrzestnego księcia: Miećsław, Masław (według Jana Długosza), Mieczysław (według Marcina Kromera); podważa się merowińskie imię Dagobert (por. Dagome iudex); dopuszcza się zdrobnienie od Michata (Panfil 2016: V).

W dyskursie rocznicowym spotykamy wzmianki o historycznych źródłach pisanych: Thietmar, Gall Anonim, Długosz. Objaśnia się nawet krytykę źródeł (Grajewski 2016: 22).

\section{Pogłębianie sensu}

W wielu wypowiedziach znamiennie ocenia się następstwa omawianego aktu sakramentalnego. Dokument Dagome iudex potwierdza powierzenie państwa Mieszka św. Piotrowi, legitymizację chrześcijańskiego władcy (Grajewski 2016: 24); mógł on narzucać podbitym plemionom jednolity państwowy kult (Śliwa 2016: 21). Podnosi się, że chrześcijaństwo przyniosło naszej ojczyźnie nowy system wartości (Dudkiewicz W. 2016: 8), naród został zakorzeniony w Chrystusie (Dudkiewicz L. 2016a: 3); „Chrzest wprowadził nasz naród w nowy świat, który wyraża się przez nową kulturę, nowe instytucje, struktury i zapisy prawne” (Rytel-Andrianik 2016: 5). Polacy, rozwijając się przez wieki w kręgu kultury i wiary chrześcijańskiej, doszli do prawdziwej wielkości: gospodarczej, kulturalnej, militarnej, politycznej i moralnej ${ }^{5}$. Następstwem chrztu jest tworzenie bardziej Bożego świata, przejawiające się w elementach kultury, szacunku i braterstwa (Skubiś 2016a: 3). Jako konsekwencję chrztu dostrzega się współczesną realizację określonych wartości: „1050 lat później najważniejszym dla Polaków hasłem jest

\footnotetext{
${ }^{5}$ Por. omówienie książki Krzysztofa Ożoga 966. Chrzest Polski ([brak autora] DB 4/2016: 30).
} 
«Bóg, honor, Ojczyzna»” (Panfil 2016: V) obok oceny, że „pod względem znaczenia politycznego i kulturowego można zestawić chrzest Mieszka z wstąpieniem Polski do Unii Europejskiej [...] chrzest ustawił nas w historii powszechnej" (Szostkiewicz 2016: 16). Optyka sądu bywa więc spolaryzowana w kierunku patriotyczno-religijnym bądź proeuropejskim.

Religijność i państwowość/narodowość. Uczestnikom dyskursu rocznicowego towarzyszy świadomość, że „narodziny państwa polskiego i jego chrzest są ze sobą ściśle związane" (Kindziuk 2016: 7)6. Jako przykład współwystępowania komponentu religijnego i państwowego $\mathrm{w}$ jednym przekazie można podać tytuł filmu Chrzestny dar w reżyserii Elżbiety Nekandy-Trepki, wykorzystany w programie dokumentalnym TVP Historia 2008, zatytułowanym Narodziny państwa polskiego, rozpowszechnionym na płycie DVD w tygodniku „Do Rzeczy”.

Sceptycznie nastawiony dziennikarz rozmawiający z profesorem historii widzi we wspólnych obchodach państwowo-kościelnych ,nową odsłonę sojuszu ołtarza z tronem", a jego rozmówca ostrzega przed ,powrotem do ideologii głoszonej przez księdza Piotra Skargę" i wyraża niepokój o ,ideologię państwową zrastającą się z wierzeniami" (Szostkiewicz 2016: 16). Spotyka się także wypowiedzi bardziej kąśliwie oceniające narodowość wobec europejskości, jak np. stwierdzenie, że Polska ,przywarowała niepewnie w marszu na Zachód” i „opatuliła się od stóp do głów narodowym pancerzem" (Szczerek 2016: 17).

Motyw pamięci, rozumianej zwłaszcza jako powracanie do początku, jest wyraźnie obecny w dyskursie rocznicowym. Pytanie o początek (arche) w wielkich kulturach, jak np. biblijna, pozostaje pytaniem o istotę, odszukiwaniem tego, co najważniejsze, po to, żeby je wyeksponować i chronić. Obchody 1000-lecia państwa, pozbawione elementów religijnych wskazuje się jako działanie zmierzające do tego, żebyśmy zapomnieli, iż Polska została ochrzczona (Skubiś 2016a: 3). Kościół troszczy się o chrześcijańskie dziedzictwo, pomny, iż narody, które tracą pamięć, giną (Skubiś 2016b: 3). Ideę początku określa się wprost w omówieniu filmu dokumentalnego Tajemnice początków Polski ${ }^{7}$, „Od chrztu wszystko się zaczęło” (Zieliński 2016: 12). Jest ona implikowana w stwierdzeniach: „Bez chrztu nie byłoby Polski” ([okładka, brak autora] DB 4/16: 1) czy też „Nie ma przed chrztem historii Polski” (Starzak 2016: 4). Metaforycznie komunikuje się początek przez odwołanie do kolebki, ziarna i źródeł: kolebką jest Gniezno (Stelmasiak 2016: 6) ,ziarno wiary zostało zasiane [...] i przez wieki dawało plony, rodząc również bezcenny dar Narodu" (Rozpiątkowski 2016: 10); powracanie do źródeł jest konieczne w drodze ku przyszłości (Rozpiątkowski 2016: 11).

Przygnębiający obraz początków Polski, z karykaturalną minimalizacją, akcentując ideę zamknięcia i terroru, $\mathrm{z}$ ironicznym dystansem wobec jubileuszu i początków państwa, maluje dziennikarz-sceptyk:

\footnotetext{
${ }^{6}$ Myśl ta wyrażana jest także w innych źródłach.

7 Tajemnice początków Polski: Wyspa władców, G 16/2016: 2, Program TV.
} 
Dziwnie mi się patrzyło na polski sztandar zatknięty na wałach grodu. Niby wiedziałem, że te kilka na krzyż budowli na tym malutkim placyku i tych kilka osób tam zamkniętych i trzymających podgrodzie pod włóczniami to były właśnie te zręby struktur państwowo-administracyjnych i prapoczątki państwa, ale coś we mnie się buntowało, że ten sztandar powiewa właśnie tam, a nie nad terroryzowaną przez gródek wsią. [...] jakim cudem watażkowie z takiego gródeczka stworzyli tak gigantyczne struktury, sięgające od Niemców po Ruś i od Pomorza po Czechy (Szczerek 2016: 17).

Wyznaje też brak poczucia więzi z miejscem i czasem początku:

To tu, w Wielkopolsce polska narracja historyczna ustawiła początki państwa, które jest moją ojczyzną, ale nie czułem z tym miejscem specjalnego związku [...] jestem z południowo-wschodniej części mapy i Wielkopolska, jako moja teoretyczna praojczyzna, jest dla mnie abstrakcją (Szczerek 2016:17).

Problem tożsamości chrześcijańskiej dochodzi do głosu w rachunku sumienia narodu: „Polsko, narodzie ludzi ochrzczonych, czy żyjesz wciąż nowością tego sakramentu?" (Dudkiewicz L. 2016d: 15). W tym duchu rozbrzmiewa gnieźnieński apel o rodzinę (Stelmasiak 2016: 6), z nawiązaniem do programu Rodzina 500+ w czasach Mieszka. Podkreśla się maryjność polskiej tożsamości chrzcielnej i osobistą relację z Bogiem każdego pokolenia Polaków, dzięki chrztowi Mieszka I (Frukacz 2016: 20).

W perspektywie europejskiej powraca pytanie Papieża-Polaka z czerwca 1980 r. w Paryżu, pobudzające do rachunku sumienia Francję, zasadne również wobec Polski: „Francjo, najstarsza córo Kościoła, co zrobiłaś ze swym chrztem?” (Markowski 2016a: 21). Przypomina się, że Europa została zakorzeniona w Chrystusie i ma wspaniałych założycieli, jak chrześcijanin Robert Schumann (Dudkiewicz L. 2016a: 3), Alcide De Gasperi czy też kanclerz katolik Konrad Adenauer - zwolennik Europy budowanej na chrześcijańskich wartościach, z wizją człowieczej godności dziecka Bożego i brata (Krzewicki 2016: 11). Chrześcijańskie początki Europy kierują myśl ku pierwszemu Zjazdowi Gnieźnieńskiemu. Wielokrotnie przypomina się, że siła i prawdziwość hasła tegorocznego zjazdu jubileuszowego Europa nowych początków. Wyzwalająca moc chrześcijaństwa uwarunkowana jest zachowaniem w przestrzeni publicznej symboli chrześcijańskich (Kowalczyk D. 2016: 38), ostrzega się Polskę i Europę przed „wypłukaniem z chrześcijaństwa" (Łoziński 2015: 5). Ojciec Maciej Zięba OP w odrzuceniu chrześcijaństwa widzi przyczynę kryzysu Unii Europejskiej, przypominając z sugestywną prostotą, że „Ewangelia zszywała Europę [...] chrześcijanie stworzyli Europę, ponieważ głosili Ewangelię, a nie program społeczno-polityczny" (Łoziński 2016: 20, 22).

Myśl przewodnia jubileuszu „Gdzie chrzest, tam nadzieja” pozwala odczytać znaki współczesności w neotradycjonalistycznej doktrynie społecznej Europy Środkowo-Wschodniej, postulującej odbudowę tożsamości na tradycyjnych wartościach połączonych z modernizacją kraju (Stelmasiak 2016: 7). Chrześcijańskie podstawy moralne przeciwstawia się ładowi opartemu na ideologii gender i tole- 
rancji zabójstwa (Szarek 2016: 8), ubolewając, że Unia Europejska zapomina o wartościach, na których została zbudowana (Wiśniewska 2016: 12). Chrzest Polski, jako źródło życia duchowego Narodu, uzasadnia apel do niego o pełną ochronę życia poczętych dzieci, będącą impulsem dla odrodzenia chrześcijańskiej cywilizacji Europy, ocalonej przez nas w 1683 i 1920 r. (Markowski 2016b: 27).

Prezentuje się miejsca poszerzające judeochrześcijański krąg cywilizacyjny wyznaczany przez Ateny-Rzym-Jerozolimę o polską „mapę Christianitatis”: Gniezno, Warszawę, Torun, Frombork, Kraków, Poznań, Brześć Litewski, Częstochowę i „setki miejscowości na kresach” (Krawczyk 2016: 13). Słowa papieskie potwierdzają, że światową listę świętych wzbogaciły wielkie postacie Polaków: św. Maksymilian Kolbe, św. Faustyna, św. Jan Paweł II (Macura 2016: 5).

\section{Język - jakiego się używa i jaki poddaje się refleksji}

Przeważająca część badanych wypowiedzi pochodzi z prasy religijnej, tzn. odwołującej się do rzeczywistości transcendentalnej, opartej o ,jasno sprecyzowany fundament wierzeń teologicznych i przekonań moralno-obyczajowych" (Łuczak 2016: 98). Mamy tu więc do czynienia z językiem religijnym. Jego użytkownikami są hierarchowie, publicyści i uczeni Kościoła katolickiego, w mniejszym stopniu - dziennikarze i uczeni świeccy, różnych zapatrywań na wartości narodowe i religijne.

Język dyskursu rocznicowego wychodzi poza obszar stylu wzniosłego czy też oficjalnego, w stronę potoczności, i to niekiedy niskiego rejestru. Podjęta tematyka angażuje autorów i ich rozmówców kompetentnych w dziedzinie historii i archeologii, teologii, filozofii, kultury i języka. Ich wypowiedzi mają często charakter popularyzujący najnowsze osiągnięcia badawcze i stanowiska interpretacyjne nieskrępowane ideologicznie.

Zainteresowanie czytelnika jest kierowane ku problemom samego języka. Znajdziemy więc etymologię terminu chrześcijanin, zawartą w cytowanych Księgach narodu polskiego i pielgrzymstwa polskiego: „Jak zwano każdego dawniej ewangeliją przyjmującego, chrześcijaninem, na znak, iż gotów krew przelać za Chrystusa" (Mickiewicz 2016: IV).

Precyzuje się podstawowe terminy, np. naród, zauważając, że w dzisiejszym rozumieniu ma on rodowód zaledwie osiemnastowieczny. Przeciwko utożsamianiu patriotyzmu z nacjonalizmem wypowiada się o. M. Zięba OP, przypominając ideę Europy ojczyzn Papieża-Polaka (por. Łoziński 2016: 22). Wyjaśnia się ścisły i symboliczny sens wyrażenia metaforycznego chrzest Polski, odnoszonego jedynie do początku ewangelizacji rodzącego się właśnie państwa (Jaklewicz 2015: 26). Uściśla się jego sens w aspekcie nazwy Polska, zapisanej dopiero w r. 998 (Panfil 2016: V). Z zarzutem upolitycznienia i ignorancji krytykuje się wizję gremialnego przyjmowania chrztu w X w. (Szostkiewicz 2016: 16). 
Myślenie ciążące ku związkowi z chrztem skutkuje nawet błędną etymologią (opartą na adideacji), jak wywodzenie słowa Polanie od czasownika polać (woda chrztu świętego) (Gancarczyk 2016: 3).

Język obserwowanego dyskursu obfituje w genologiczną terminologię religijną (tu lokalizację pomijam): katecheza, świadectwo, przyrzeczenia chrzcielne, modlitwa, akt zawierzenia; spotyka się nazwy form liturgicznych, jak Eucharystia, śpiew. Wymienia się gatunki mówionej i pisanej refleksji naukowej nad treściami Ślubów Jasnogórskich: dysputę z cyklu Raport jasnogórski ([bez autora] 2016 N 38/ 2015: 27), sympozjum naukowe zatytułowane Dziedzictwo Świętego Krzyża. Sacrum - Kultura - Natura ([zapowiedź] G 13/2016: 8), monografię historyczno-statystyczną 1050 lat chrześcijaństwa w Polsce (Dudziński 2016: 6) (kilkakrotnie).

Temat wydarzenia patriotyczno-sakralnego z głębi wieków średnich realizuje się z dbałością o autentyzm strony językowej przekazu. W dyskursie pojawiają się cytaty łacińskich zapisów historycznych, haseł, np. wzmianki w rocznikach polskich: Dubravka venit ad Mesconem oraz Mesco Dux baptizatur (Łuczak 2016: 11). Sama formuła łacińska z tłumaczeniem Mesco dux baptizatur, czyli Książe Mieszko ochrzczony widnieje w tytule filmu dokumentalnego (Kabiesz 2016: 3). Napotkamy znaną dewizę Polonia semper fidelis (Rozpiątkowski 2016: 10), nazwy formacji państwowych: Imperium Christianum, Regnum Poloniae (Wroński 2016: VIII) a nawet szacowną konstrukcję archaiczną, skonstruowaną na sposób makaroniczny „mapa Christianitatis” (Krawczyk 2016: 13).

Wiele miejsca poświęca się symbolice. Do młodego audytorium kierowane jest wyjaśnienie: „dzięki prostym gestom i przedmiotom możemy lepiej zrozumieć treść naszej wiary [...] Na Lednicy zmieniamy znaczenie przysłowiowego «gadżetu» na «symbol» i «znak»"8. Szeroko i dogłębnie, z egzemplifikacją historyczną, przedstawiona jest polska symbolika kolektywna ${ }^{9}$, przede wszystkim krzyż, a także związek symbolu narodowego z chrześcijańskim: Orzet i Krzyżio,

${ }^{8}$ Powiedz: Amen!, [zapowiedź] ([notka redakcyjna], N 20/2016: 48).

${ }^{9}$ M. Fleisher przez symbole kolektywne rozumie 'jednostki funkcjonalne, wykazujące silne pozytywne lub negatywne nacechowanie oraz - równocześnie - znaczenie kulturowe' (2003: 107-108).

${ }^{10}$ Tezę, że Krzyż przestał być tylko symbolem religijnym, a stał się symbolem walki o Polskę, popiera katalog bohaterów polskiej historii związanych z Krzyżem. Widzimy Mieszka I całującego Krzyż. Działanie Boże w walkach z Tatarami dokumentują bł. Czesław, Henryk Pobożny, synod w Łęczycy, strzegący polszczyzny; Krzyż jest obecny w Gnieźnie (Przemysł II), na jabłku królewskim Kazimierza Wielkiego, w ręce św. Andrzeja Boboli; na Jasnej Górze w rękach ks. Kordeckiego, w świątyni lwowskiej przy ślubach Jana Kazimierza, nad Kahlenbergiem, gdzie modlił się król Sobieski, na pancerzach husarzy (wraz z Matką Boską), u konfederatów barskich (w obronie wiary i Ojczyzny), pod Racławicami. Koło Krzyża idą Legioniści Piłsudskiego, z nim w dłoni ginie w bitwie z bolszewikami w 1920 ks. I. Skorupka [...] opierał na nim czoło ks. J. Popiełuszko, błogosławił św. Jan Paweł II. Wskazuje się miejsca Krzyża typowe dla charakterystycznych okoliczności: na rzemyku pod bluzą legionisty, w kościele, podczas Mszy polowej Żołnierzy Wyklętych, w wojskowym szpitalu, w więzieniu w Szczypiornie, w Katyniu, Starobielsku, Ostaszkowie, krzyżyk różań- 
por. także Krzyż i Orzet, pieśń biskupa Józefa Zawitkowskiego (2016: 13). Podkreśla się wymowną symbolikę monstrancji i krzyża z tysiącletniego dębu (Babuchowski 2016: 7), jak też chrzcielnicy 'źródła życia' (Drzewiecki 2016: 9). Nawet ulewny deszcz - okoliczność klimatyczno-pogodową dyskursu - zinterpretowano w symbolice chrzcielnej jako znak obfitości łaski Boga w Roku Miłosierdzia, jak i znak odnowienia chrztu w rocznicę 1050-lecia Chrztu Polski (Kowalczyk M. 2016: 56). Jezioro Lednickie nazwane zostało sakramentem Boga, z ewangeliczną aluzją do kroczenia Chrystusa po wodzie, rozumianą symbolicznie: „Chrystus, krocząc po jego wodach, przyszedł do nas, Polaków, w chrzcie świętym" (Dudkiewicz L. 2016b: 3). Zauważa się częstą w homiliach i przemówieniach symbolikę korzeni i drzewa (Rozpiątkowski 2016: 11), wody, deszczu, źródła.

Krytyk tegorocznych uroczystości rysuje językiem kultury popularnej i slangu sposób ich przebiegu, z zarzutem infantylizmu. Dotyka też ironią języka obchodów, stylizowanego archaicznie (staropolszczyzną) i kościelnie (uwznioślanego), wszakże z dodatkiem w nowym języku globalnym, tzn. angielskim: „Polscy politycy radośnie uprawiali politykę historyczną w wersji «kolorowanka patriotyczna»" (Szczerek 2016: 18); mówi się o napakowanych nacjonalistach, którzy wbili się na wieczór autorski lewicowego publicysty w Gnieźnie - „chrzcielnicy Polski”, o „rozwrzeszczanych bojówkach ONR” i przemawiającym do nich z kościelnej trybuny „kryptofaszystowskim księdzu Międlarze”" dych wolontariuszy z identyfikatorami podpisanymi: „Rozesłanie”, „Korowód świętych", nie pomijając napisu na drogowskazie do karczmy ,jadło" tuż obok umieszczonego „na wszelki wypadek: «food»”.

Minimalizacji uroczystości i jej podstawy historyczno-patriotycznej służą środki słowotwórcze i leksykalne: te kilka na krzyż budowli, malutki placyk, tych kilka osób, watażkowie z takiego gródeczka. Deprecjacji dokonuje się przez nazwy - etykietki: chata wuja Mieszka, chrzest do pokolorowania, kolorowanka $\mathrm{z}$ asocjacją lekturki szkolnej lub książeczki przedszkolnej. Językowy autentyzm potocznej wypowiedzi taksówkarza wzmacnia konfrontację państwowych działań solemnizacyjnych - obecnych z poprzednimi: „Komuniści to przynajmniej szkoły pobudowali na tysiąclecie [...] A ci tylko autokarów nawieźli pod stadion, i tyle". Wzniosłość zderzona z potocznością ośmiesza uczestników opisywanej uroczystości: kapłani procesyjnie wchodzący na murawę stadionu wyglądali, jakby zaraz mieli „rozbiec się po stadionie i grać w nogę” (Szczerek 2016: 16-18).

Zgromadzenie Narodowe określono jako Parlament Dziecięcy/Sejm dziecięcy, używający języka mitów zamiast języka nauki (historii); jego wypowiedzi zyskały miano bajania. Wykpiono styl podniosły przemówienia głowy państwa. Końco-

cowy w smoleńskim błocie w 2010 r.; Krzyż podejmowany przez kolejne pokolenia Polaków (por. Łysiak 2016: II-III).

${ }^{11}$ Wszystkie cytaty i omówienia w tym i następnym akapicie pochodzą z artykułu Chrzest do pokolorowania Z. Szczerka (2016: 16-18). 
wy zwrot błogosławiący oceniono jako chybione naśladowanie amerykańskiego God bless America ${ }^{12}$ :

Prezydent wygłaszał coś w rodzaju kazania okrągłymi zdaniami [...] zakończył [...] słowami: „Niech Pan Bóg błogosławi mojej ojczyźnie, Polakom, Kościołowi”, i zabrzmiało to tak, jakby chciał wzorem amerykańskim, powiedzieć „God bless Poland”, ale lokalne okoliczności nie pozwoliły na tak proste ujęcie sprawy i trzeba było kombinować (Szczerek 2016:18).

Tezę, że religijny wymiar obchodów przytłacza popkultura: szaliki, obecność w sieci, amatorskie wideoklipy (Sarzyński 2016: 91) popiera bezceremonialny tytuł felietonu Mieszko, Mieszko, mój koleżko (z rapowanego kabaretowego tekstu imitującego szkolne opracowanie historyczne), sygnalizujący totalny brak szacunku (Sarzyński 2016: 89).

Szyderczy ton przybiera podsumowanie wizji oficjalnych obchodów kościelno-państwowych [...] ,z pełnym zaangażowaniem A. Dudy, który będzie podążał za hierarchami przez wszystkie te dni i modlił się w podziękowaniu za słuszną decyzję Mieszka I" (Sarzyński 2016: 91).

W tekstach dystansujących się od postawy czci widać mechanizmy kpiny, ironii - mieszanie, kontrastowanie środków stylistycznych: slang (język ulicy), subkultury popularnej, język literatury dziecięcej, kibiców sportowych, verba condemnanda, ale także styl wyższy (język naukowy, religijny, język mitów), eksponujący verba miranda. Wypowiedzi aprobatywne też operują różnymi stylami, oscylującymi między intelektualnym i emocjonalnym, nie gardząc potocznym - w zależności od odbiorców i okoliczności.

\section{Wnioski}

Naród jest kontynuacją, ale myślenie o nim - nie. Zbiorowy podmiot, który tworzy obraz świata - czy przez odwołanie do tradycji, czy przez swoje aktualne aspiracje (autostereotyp grupowy) należy do kategorii homo politicus - człowiek aktywnie uczestniczący w życiu społecznym (Bartmiński 2012: 208). Wypowiedzi skupione wokół rocznicy Chrztu Polski to ważna część współczesnego polskiego dyskursu tożsamościowego ${ }^{13}$. Mimo dysproporcji w wyborze źródeł można zauważyć, że różnią się one wartościowaniem historyczności, sakralności, patriotyzmu i europejskości w kontekście konstytutywnego wydarzenia i jego rocznicy.

${ }^{12}$ Gwoli ścisłości zauważmy, że w amerykańskim dyskursie patriotycznym mówienie o ojczyźnie przyjmuje ramę sakralizującą werbalnie, ale obligatoryjność i petryfikacja formuły odbiera jej autentyczność. Ten sam zwrot amerykański cytowany w polskim dyskursie medialnym nawet w ustach amerykańskiej gubernator mógł zabrzmieć autentycznie dla polskiego odbiorcy (por. Sobczykowa 2012: 73-88).

${ }^{13}$ Ze względu na wyraźną często, co zrozumiałe, intencję pouczającą, tworzą one zarazem dyskurs edukacyjny (por. Skudrzykowa, Warchala 2002: 277-284). 
Współczesnych Polaków cechuje orientacja prezentystyczna - językowa konceptualizacja czasu społecznego nastawiona na chwilę bieżącą. Sięganie w przeszłość nie jest Polakom obce, chociaż współczesny dyskurs publiczny operuje na ogół potoczną koncepcją czasu, dotykającą zmian w życiu politycznym ostatnich lat, nie zaś głębi dziejów (por. Bartmiński 2012: 215). Wydarzenie rocznicowe wymagało wyjścia poza problematykę skupioną na teraźniejszości lub bliskiej przeszłości.

Myślenie o Polsce jako o swoim kraju czy też narodzie w głąb historii skutkuje napotkaniem koegzystencji wartości narodowych i sakralnych, i wydobyciem jej na jaw, mimo że współcześnie postuluje się izolowanie świeckiego od religijnego, a nawet wypieranie wartości sakralnych z dyskursu publicznego. Pojawia się wątpliwość, czy chrześcijaństwo jest jeszcze wyróżnikiem polskiej tożsamości. Różnica między obchodami tegorocznymi a tymi sprzed półwiecza - w czasie domagającym się takiej refleksji, ale jej pozbawionym - znalazła językowy wyraz w ich oficjalnych nazwach, różnie sprofilowanych: ówczesnych Millennium i Tysiąclecie państwa oraz współczesnej rocznica Chrztu Polski. Świadomość wydarzenia fundującego zręby Polski jako chrześcijańskiej wspólnoty państwowej zaznacza się mocno, chociaż nie u wszystkich uczestników dyskursu. Poznaliśmy charakterystyczne postawy nie tylko tych, którym łatwo przychodzi wiązanie wartości narodowych z sakralnymi, ale i kontestatorów takiego przekonania, których wrażliwość na „tchnienie ducha”, a i poczucie więzi z przodkami znacznie osłabły. Kontestuje się zasadność daty rocznicowej, wagę omawianego faktu, motywację władcy, związek narodu z sacrum, łączność z krainą początku, chrześcijaństwo współczesnych Polaków.

Językiem honorującym symbole kolektywne komunikują się nie tylko duchowni - ludzie Kościoła, który zawsze był i jest strażnikiem wartości. Dyskurs rocznicowy ujawnia mapę mentalną Polaków wypełnioną wieloma miejscami (łączonymi z postaciami) chrześcijaństwa, sięgającymi w głąb dziejów, wciąż stanowiącymi dziedziczoną wartość wspólnotową dla bardzo wielu ${ }^{14}$ i skłania do refleksji nad rozumieniem i wyrażaniem współczesnego patriotyzmu przez polską inteligencję ${ }^{15}$.

Różnice w interpretacji decyzji pierwszego polskiego historycznego władcy dotyczą też oceny jego ,proeuropejskości”, skorelowanej z poglądami współczesnych uczestników dyskursu na problem tożsamości europejskiej, która zwykle jest kojarzona z osłabieniem poczucia narodowego i chrześcijaństwa. A jednak socjologowie wśród historycznych i współczesnych cech tożsamości europejskiej

14 „Mapa mentalna ma charakter wybiórczy [...] i narodowo nacechowany”, służąc wartościowaniu obiektów, łączących się w grupy według podobieństwa lub przeciwieństwa ich cech i wartości (Chlebda 2002: 9-26).

${ }^{15}$ Badacz tej problematyki z troską o etos owej elity społeczeństwa proponuje „«〈uzgodnienie»〉 nowoczesności z najwartościowszą częścią polskiego dziedzictwa [...] żeby Polak odnalazł się w nowoczesności, nie tracąc przy tym związków z twórczą energią skumulowaną w głębinach żywej tradycji narodowej” (Szkołut 2010: 158). 
wymieniają między innymi uniwersalistyczne wartości chrześcijańskie i wspólnotę ducha, przypisywaną głównie autorom katolickim (por. Łastawski 2004: 208).

W dyskursie skupionym wokół faktu inicjującego chrześcijaństwo i państwowość narodu zaznaczyły się różne postawy uczestników wobec przekazywanej idei, niejednolite cele komunikacyjne, uwikłania światopoglądowe, osłabione poczucie wspólnoty kulturowej i narodowej, a zarazem duża swoboda i wyrafinowane posługiwanie się językiem... czasem dalekim od języka wartości.

\section{Skróty tytułów czasopism}
A - „Angora”
DB - „Don Bosco"
G - „Gość Niedzielny”
GP - „Gazeta Polska”
$\mathrm{N}-$,Niedziela”
P - „Polityka”
Ź - „Źródło"

\section{Bibliografia}

\section{A. Podmiotowa (Spis źródeł)}

Babuchowski S., 2016, Monstrancja i krzyż z tysiącletniego dębu, „Gość Niedzielny”, nr 14, s. 7.

[brak autora], 2016, 966. Chrzest Polski [omówienie książki: Krzysztof Ożóg, 966. Chrzest Polski. Wydawnictwo Biały Kruk 2015], „Don Bosco”, nr 4, s. 30.

Drzewiecki P., 2016, Amen, „Niedziela”, nr 24, s. 9.

Dudkiewicz L., 2016a, Nasze narodowe DNA, „Niedziela”, nr 20, s. 3.

Dudkiewicz L., 2016b, Ostatni artykut ojca Jana Góry, „Niedziela”, nr 23, s. 3.

Dudkiewicz L., 2016c, W kolebce naszego życia na wieki, „Niedziela”, nr 17, s. 3.

Dudkiewicz L., 2016d, Wiara się podzielić. Rozmowa z abp. Wojciechem Polakiem, „Niedziela", nr 8, s. 14-15.

Dudkiewicz L., 2016e, Wszystko, co Polskę stanowi, oddajemy Maryi, „Niedziela”, nr 18, s. 3.

Dudkiewicz W., 2016, Ku czci św. Wojciecha, „Niedziela”, nr 18, s. 8.

Dudziński W., 2016, Liczby mówiq wiele, „Niedziela”, nr 18, s. 6.

Frukacz M., ks., 2016, 800 czytelników Niedzieli na pielgrzymce. Pytania o tożsamość chrześcijańska, „Niedziela”, nr 18, s. 20.

Gancarczyk M., ks., 2015, Chrzest z wiary czy z polityki?, „Gość Niedzielny”, nr 49, s. 3. Gancarczyk M., ks., 2016, My, ludzie z wody, „Gość Niedzielny”, nr 16, s. 3.

Grajewski A., 2015, Jak Dąbrówka Mieszka nawrócita, „Gość Niedzielny”, nr 49, s. 36-37.

Grajewski A., 2016, Nasze DNA. Rozmowa z bp. Grzegorzem Rysiem, „Gość Niedzielny”, nr 16, s. 22-24.

Jaklewicz T., ks., 2015, Chrzest, czyli co?..., „Gość Niedzielny”, nr 16, s. 26-27. 
Jaklewicz T., ks., 2016, Gorace lato w Krakowie, „Gość Niedzielny”, nr 1, s. 21.

Kabiesz E., 2016, Sceny chrztu Mieszka I do filmu Mesco dux baptizatur, czyli Ksiażę Mieszko ochrzczony zostaty nakręcone w romańskiej katedrze w Cieszynie, „Gość Niedzielny", nr 16, Program TV na tydzień, s. 3.

Kindziuk M., 2016, Urodziny Kościoła i państwa, „Niedziela”, nr 5, s. 7.

Kluba M., 2015, ŚDM w kraju Bożego miłosierdzia, „Gość Niedzielny”, nr 50, s. 40-41.

Kowalczyk D., ks., SJ, 2016, Gdy was dzieci zapytają..., „Gość Niedzielny”, nr 1, s. 38.

Kowalczyk M., 2016, Powiedz Amen, „Niedziela Młodych”, nr 24, s. 56-57.

Krawczyk E., 2016, Zgromadzenie narodowe w Poznaniu. Fundament pokoleń, „Niedziela", nr 17, s. 13.

Krzewicki J., ks., 2016, Prekursorzy jedności Europy, „Niedziela”, nr 10, s. 10-11.

Łoziński B., 2015, Rzad wesprze obchody 1050. rocznicy Chrztu, „Gość Niedzielny”, nr 49, s. 5.

Łoziński B., 2016, Ewangelia zszywała Europę, [Rozmowa z o. Maciejem Ziębą OP], „Gość Niedzielny”, nr 28, s. 20-22.

Łuczak M., ks., 2016, Naród tonacy w ciemnościach ujrzat świattość, „Niedziela”, nr 15, s. $10-11$.

Łysiak W., 2016, Orzet i Krzyż, „Gazeta Polska”, nr 15, s. II-III.

Macura A., 2016, Franciszek napisat list do Polaków, „Gość Niedzielny”, nr 16, s. 5.

Markowski A., 2016a, Ocalić Europę, „Niedziela”, nr 24, s. 20-21.

Markowski A.,2016b, Światto prawdy, która zwycięża, „Niedziela”, nr 26, s. 27.

Mickiewicz A., 2016, Księgi narodu polskiego i pielgrzymstwa polskiego [fragment], „Gazeta Polska”, nr 15, s. IV.

[Notka redakcyjna 1], 2016, Chrzest Polski-nasze DNA, [temat numeru] „Gość Niedzielny", nr 16, s. 3.

[Notka redakcyjna 2], 2016, Powiedz: Amen!, [zapowiedź], „Niedziela”, nr 20, s. 48-49.

[Notka redakcyjna 3], 2016, Sympozjum naukowe [zapowiedź], „Gość Niedzielny”, nr 13, s. 8.

[Notka redakcyjna 4], 2016, Tajemnice początków Polski: Wyspa władców, „Gość Niedzielny", nr 16 - Program TVP, s. 2.

[Notka redakcyjna 5], 2016 Wieczór 206 [zapowiedź], „Niedziela”, nr 16, s. 42.

Nowak A., 2015, Czy pamiętacie, że jesteście Narodem dumnym ze swej ponadtysiacletniej tradycji, czy czujecie więź z rodakami?, „Precz z biała gęsia” - raz jeszcze, „Gość Niedzielny", nr 49, s. 74.

[Okładka 1], 2016, Polsko, ja ciebie chrzcze..., „Gość Niedzielny”, nr 16, s. 1.

[Okładka 2], 2016, Od czasów Mieszka I oddychamy chrześcijaństwem, „Niedziela”, nr 17 , s. 1.

Panfil T., 2016, Chrzest Polski, „Gazeta Polska”, nr 15, s. IV-VI.

Rastawicka A., 2015, Przymierze z Maryją. Jasnogórskie śluby narodu, „Niedziela”, nr 38, s. 26-27.

Rozpiątkowski P., ks., 2016, Polska zawsze wierna, „Niedziela”, nr 17, s. 10-12.

Różycki K., 2016, Jak to ze chrztem było. Rozmowa z prof. A.M. Wyrwa, dyrektorem Muzeum Pierwszych Piastów na Lednicy, „Angora”, nr 15, s. 14-16.

Rytel-Andrianik P., ks., 2016, Gdzie chrzest, tam nadzieja, „Niedziela”, nr 15, s. 5.

Sarzyński P., 2016, Mieszko, Mieszko, mój koleżko, „Polityka”, nr 15, s. 89-91.

Skubiś I., ks., 2016a, Nie jesteśmy na zawsze, „Niedziela”, nr 18, s. 3.

Skubiś I., ks. 2016b, Chrzcielnica - źródło życia, „Niedziela”, nr 23, s. 3. 
Starzak G., 2016, Bez chrztu nie byłoby Polski. Rozmowa z prof. Andrzejem Nowakiem, „Don Bosco”, nr 4, s. 4-7.

Steele Ph., 2016, Nawrócenie i chrzest Mieszka I, Kraków.

Stelmasiak A., 2016, Podróż do źródła Polski, „Niedziela”, nr 12, s. 6-7.

Szarek J., 2016, Powrócić do duchowych źródeł Polski, „Źródło”, nr 18, s. 7-9.

Szczerek Z., 2016, Chrzest do pokolorowania, „Polityka”, nr 17, s. 16-18.

Szostkiewicz A., 2016, Chrzest jak Unia... Rozmowa z prof. Henrykiem Samsonowiczem, historykiem, o pożytku i użytkach z chrztu przyjętego przez Mieszka I 1050 lat temu, „Polityka”, nr 16, s. 14-16.

Śliwa L., 2016, Ojciec chrzestny, „Gość Niedzielny”, nr 16, s. 18-21.

Tomoń S., o., OSPPE, 2016, Polscy biskupi oddali naród Maryi, „Niedziela”, nr 20, s. 8-9.

Wakuła P., 2016, Po prostu biznes [Humoreska], „Angora”, nr 17, s. 2.

Wiśniewska J., 2016, Feminizm ponad demokracją. Ideologia ponad zdrowym rozsadkiem, „Niedziela”, nr 10, s. 12.

Wroński A, 2016, Imperium Christianum?, „Gazeta Polska”, nr 15, s. VII-VIII.

Zawitkowski J., bp, 2016, „Krzyż i Orzel” na 1050-lecie Chrztu Polski, „Niedziela”, nr 6, s. 13.

Zieliński T., 2016, Od chrztu wszystko się zaczęło, „Niedziela”, nr 15, s. 12-13.

Żaryn J., 2016, Stolica Apostolska bliska tysiącletniej Polsce, „Niedziela”, nr 5, s. 35

\section{B. Przedmiotowa}

Bartmiński J., 2012, Zmiany obrazu świata Polaków we wspótczesnym dyskursie publicznym, w: Idem, Językowe podstawy obrazu świata, Lublin, s. 208-225.

Chlebda W., 2002, Polak przed mapa mentalna świata, „Etnolingwistyka”, t. 14, s. 9-26.

Fleisher M., 2003, Stabilność polskiej symboliki kolektywnej, w: Język w kręgu wartości. Studia semantyczne, red. J. Bartmiński, Lublin, s. 107-143.

Langkammer H., 1994, Słownik biblijny, Katowice.

Łastawski K., 2004, Historyczne i współczesne cechy tożsamości europejskiej, „Polityka i Społeczeństwo", nr 1, s. 206-237.

Łuczak M., 2016, Dyskurs autopromocyjny w prasie religijnej na przykładzie tygodników „,Gość Niedzielny” i „,Niedziela”. Zagadnienia wstępne, w: Dyskurs autopromocyjny dawniej i dziś, red. I. Loewe, E. Tyc, A. Kalisz, Katowice, s. 97-106.

Skudrzykowa A., Warchala J., 2002, Dyskurs edukacyjny a kompetencja interakcyjna, w: Czynności tworzenia i rozumienia wypowiedzi, „Studia Pragmalingwistyczne” 3, red. J. Porayski-Pomsta, Warszawa, s. 277-284.

Sobczykowa J., 2012, Stownictwo sakralne w polskim dyskursie publicznym, w: Wortsemantik. Zwischen Säkularisierung und (Re)sakralisierung öffentlicher Diskurse, Herausgegeben von A. Nagórko, Hildesheim-Zürich-New York, s. 73-88.

Szadura J., 1993, Z badań nad autostereotypem Polaka. Kryteria polskości, w: Nazwy wartości. Studia leksykalno-semantyczne I, red. J. Bartmiński, M. Mazurkiewicz-Brzozowska, Lublin, s. 239-256.

Szkołut T., 2010, Dyskurs o etosie inteligencji polskiej w epoce transformacji ustrojowej, ze szczególnym uwzględnieniem inteligencji humanistycznej, w: Przeobrażenia w kul- 
turze i edukacji na przełomie XX i XXI w., red. M. Karwatowska, A. Siwiec, Chełm, s. $145-159$.

Wojtak M., 2011, Dyskurs religijny, styl religijny i zjawiska pokrewne, w: Eadem, Wspótczesne modlitewniki w oczach językoznawcy. Studium genologiczne, Tarnów, s. 28-45. 